Genome

AUG 2001; 44(4) : 735-737

(C) 2001 NRC

The original publication is available at http://pubs.nrc-cnrc.gc.ca
Archimer http://www.ifremer.fr/docelec/ Archive Institutionnelle de l'Ifremer

\title{
Evidence of differential chromosome loss in aneuploid karyotypes of the Pacific oyster, Crassostrea gigas
}

\author{
A. Leitão ${ }^{1}$, P. Boudry ${ }^{2}$ and C. Thiriot-Quiévreux ${ }^{1 *}$ \\ ${ }^{1}$ Observatoire Océanologique, UPMC - CNRS INSU, BP 28, 06230 Villefranche-sur-Mer, France. \\ ${ }^{2}$ Laboratoire de génétique et pathologie, Station Ifremer, BP 133, 17390 La Tremblade, France. \\ *: Corresponding author : catherine.thiriot@obs-vlfr.fr
}

\begin{abstract}
The G-banding technique was performed on aneuploid karyotypes from gill tissue of the Pacific oyster Crassostrea gigas in order to assess whether chromosome losses may be explained by differential chromosomal susceptibility and to clarify the negative correlation between aneuploidy and growth rate previously reported in different populations of this oyster. The study of $95 \mathrm{G}$-banded aneuploid karyotypes showed that only four out of the ten chromosome pairs (pairs nos. 1, 5, 9 and 10) of $C$. gigas were affected by the loss of one homologous chromosome. Pairs 1,9 and 10 , which were lost in 56, 33 and $44 \%$ of cases respectively, may be considered as differentially affected. Hypotheses on this differential chromosomal susceptibility are discussed.
\end{abstract}

Key words: aneuploidy / growth / G-banding / karyotype / oyster

Résumé: La technique de marquage en bandes $\mathrm{G}$ a été utilisée sur des caryotypes aneuploïdes, à partir de tissu branchial de l'Huître Crassostrea gigas, pour déterminer si les pertes de chromosomes pouvaient correspondre à une prédisposition chromosomique différentielle et expliquer la corrélation négative entre l'aneuploïdie et le taux de croissance observée précédemment dans plusieurs populations de cette espèce. L'étude de 95 caryotypes aneuploïdes marqués en bandes $\mathrm{G}$ a montré que seulement quatre parmi les dix paires de chromosomes de $C$. gigas $\left(n^{\circ} 1,5,9\right.$ et 10) étaient affectés par la perte d'un des deux homologues. Les paires 1,9 et 10, avec des pourcentages de 56, 33 et $44 \%$ respectivement, peuvent être considérées comme préférentiellement affectées. Des hypothèses sur cette prédisposition sont discutées.

Mots clés: aneuploïdie / croissance / bandes G / caryotype / Huître 
Previous studies have revealed the occurrence of aneuploid cells in different populations of Crassostrea gigas Thunberg. Aneuploidy was seen as the alteration of the normal diploid chromosome number $(2 \mathrm{n}=20)$ in hypodiploid cells with $2 \mathrm{n}=19,18$ or 17 (Thiriot-Quiévreux 1986; Thiriot-Quiévreux et al. 1992). Moreover, a consistent negative correlation between aneuploidy and growth rate has been repeatedly demonstrated over a ten year period (Leitão et al. 2000). One limitation to the better understanding of the aneuploidy phenomenon in C. gigas and its relationship with growth was lack on information whether chromosome losses correspond to differential chromosomal susceptibility or if this was a random process. In the present paper, the G-banding technique (Sumner et al. 1971) which permits the individual identification of each chromosome pair in C. gigas (Leitão et al. 1999) was applied to aneuploid karyotypes in order to identify the missing chromosomes.

Because cell culture is not yet available for molluscs, whole juvenile Crassostrea gigas, originating from hatchery crosses (made at IFREMER-La Tremblade, Charente Maritime, France), were incubated for 6 hours in a $0.005 \%$ solution of colchicine in sea water. The gills were then dissected out and treated for $30 \mathrm{~min}$ in $0.9 \%$ sodium citrate, then fixed in a freshly prepared mixture of absolute alcohol and acetic acid (3:1) with three changes of 20 min each. Slide preparations were made from pieces of gill tissue from each animal, using an air drying technique (Thiriot-Quiévreux and Ayraud 1982). G-banding was performed by the ASG method (Acetic/Saline/Giemsa) after Sumner et al. (1971). Photographs of G-banded metaphases were taken with a Zeiss III photomicroscope. Karyotypes of aneuploid metaphases were made on the basis of length, centromere position and banding pattern.

The analysis of 95 G-banded aneuploid karyotypes of Crassostrea gigas showed that only four out of the ten chromosome pairs were affected by chromosome loss (pairs nos. 1, 5, 9 and 10). Chromosome losses were observed either from one pair (Fig. 1 A) or from more than one pair (Fig. B and C) per karyotype. No cases of the loss of both homologues of one pair were observed. Percentages of chromosome loss, independently calculated for each pair in the 95 analysed karyotypes, were 56, 19, 33, and $43 \%$ for pairs 1, 5, 9 and 10 respectively. A Chi-squared test indicated that these chromosome losses are not random. The percentages of chromosome loss observed in pair 5 were significantly lower than in the other three pairs. Thus, pairs nos. 1, 9 and 10 can be considered as those predominantly affected in cases of aneuploidy.

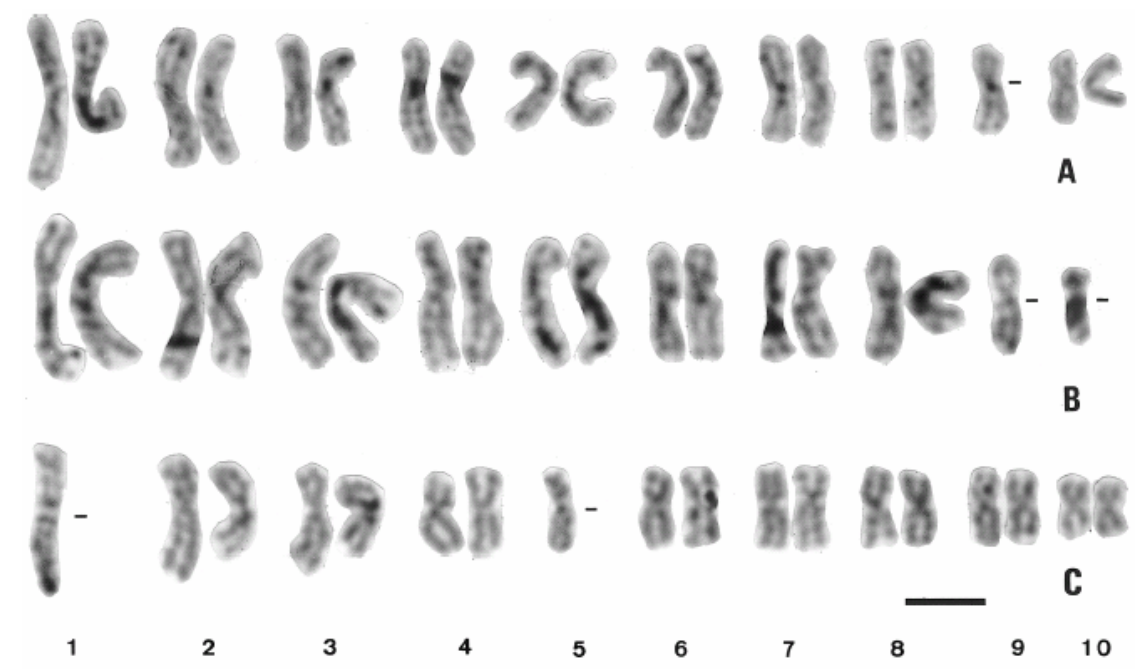

Fig.1 : G-banded aneuploid karyotypes of Crassostrea gigas. A : chromosome loss in pair 9 ; B : chromosome loss in pairs 9 and 10 ; $\mathrm{C}$ : chromosome loss in pairs 1 and 5.

Scale bar $=5 \mu \mathrm{m}$. 
The phenomenon of aneuploidy has been particularly well documented in higher mammals such as humans (Bond and Chandley 1983; Wenger et al. 1984; Bishop et al. 1996; McFadden and Friedman 1997). It has also been reported in several other organisms, such as yeast (Oshiro and Winzeler 2000) and oysters (e.g. Thiriot-Quiévreux 1986; Wang et al. 1999; Leitão et al. 2000), the subject of the present paper. Aneuploidy has often been associated with growth retardation in higher animals (Vig and Sandberg 1987). In humans, growth retardation in Turner syndrome may be explained by aneuploidy (Haverkamp et al. 1999). A negative correlation between size of chromosomes and their loss has also been shown in humans (e.g. Martin and Rademaker 1990). Brown et al. (1983) suggested that the mitotic and/or meiotic non-disjunction responsible for the aneuploidy would favour the preferential survival of cells which had lost a small sized chromosome rather than those having lost a large one, because fewer genes are lost in the first case. The fact that small sized chromosomes present fewer chiasma during meiosis I also supports the hypotheses that these should be the ones which would more easily experience non-disjunction (Verma 1990). In chemically induced aneuploidy, Bourner et al. (1998) observed that certain chromosomes were more frequently involved in aneuploid situations. The loss of the smallest pairs in $C$. gigas aneuploid karyotypes may be due to a negative correlation between chromosome size and chromosome loss such as that observed in humans (Martin and Rademaker 1990). In addition, a relationship between NOR association and the non-disjunction phenomenon, the main cause of aneuploidy, is suggested by most authors (e.g. Verma 1983; Hassold et al. 1987; Lee Gould et al. 1987). In C. gigas, the NORs are located on pair no.10 (ThiriotQuiévreux and Insua 1992), which could explain the high level of chromosome loss observed in that pair. The high incidence of chromosome loss in pair 1 is more difficult to explain since, being a large sized chromosome, it might possess a large number of genes and consequently its loss would be less tolerated. But, if this chromosome is highly heterochromatic, i.e with a large amount of repetitive DNA sequences that are not transcribed (Verma 1988), its loss would be better tolerated by the cells. This hypothesis is supported by previous observations of a relationship between heterochromatic presence and aneuploidy (Andreata et al. 1993; Rupa et al. 1997). However, the staining of the constitutive heterochromatin by C-banding has not been successful in C. gigas up till now. The negative relationship observed between aneuploidy and growth may also indicate that genes with specific functions involved in growth are located on these missing chromosomes.

In conclusion, our study highlights that losses of chromosomes in Crassostrea gigas are not random but reflect differential chromosome susceptibility. These results open a field for new investigations.

\section{Acknowledgements}

Part of this research was supported by the EU contract "GENEPHYS" (FAIR PL 95.421). We thank Dr A. Gérard for the management of this project, S. Heurtebise and S. Sabini for technical assistance, R. Ben Hamadou for statistical analysis and the teams in La Tremblade for the hatchery and nursery work. We are grateful to Dr H. McCombie for English editing.

\section{References}

Andreata, A.A., do Almeida-Toledo L.F., Oliveira C., and Toledo Filho, S. 1993. Chromosome studies in Hypoptopomatinae (Pisces, Siluriformes, Loricariidae): II. ZZ/ZW system, B chromosomes, and constitutive heterochromatin differentiation in Microlepidogaster leucofrenatus. Cytogenet. Cell Genet. 63: 215-220. 
Bishop, J.B., Dellarco, V.L., Hassold, T., Ferguson, L.R., Wyrobek, A.J., and Friedman, J.M. 1996. Aneuploidy in germ cells: etiologies and risk factors. Environ. Mol. Mutagen. 28: 159-166.

Bond, D.J., and Chandley, A.C. 1983. Oxford Monographs on medical genetics no. 11. Oxford University Press.

Bourner, R.D., Parry, E.M., and Parry, J.M. 1998. Chemically induced aneuploidy: investigations into chromosome specific effects in mitosis. Mutat. Res. 404: 191-197.

Brown, T., Fox, D.P., Robertson F.W., and Bullock, I. 1983. Non-random chromosome loss in PHA-stimulated lymphocytes from normal individuals. Mutat. Res. 122: 403-406.

Hassold, T., Jacobs, P.A., and Pettay, D. 1987. Analysis of nucleolar organizing regions in parents of trisomic spontaneous abortions. Hum. Genet. 76: 381-384.

Haverkamp, F., Wolfle, J., Zerres, K., Butebandt, O., Amendt, P., Hauffa, B.P., Weimann, E., Bettendorf, M., Keller, E., Muhlenberg, R., Partsch, C.J., Sippel W.G., and Hoppe, C. 1999. Growth retardation in Turner syndrome: aneuploidy, rather than specific gene loss, may explain growth failure. J. Clin. Endocr. Metab. 84: 4578-4582.

Lee Gould, S., and Martin De Leon, P.A. 1987. Brdu-giemsa labeling studies of satellite association in parents of children with trisomic 21 or 13. Am. J. Med. Genet. 26: 971981.

Leitão, A., Thiriot-Quiévreux, C., Boudry P., and Malheiro, I. 1999. A "G" -chromosome banding study of three cupped oyster species: Crassostrea gigas, Crassostrea angulata and Crassostrea virginica (Mollusca:Bivalvia). Genet. Sel. Evol. 31: 519-527.

Leitão, A., Boudry, P., and Thiriot-Quiévreux, C. 2000. Negative correlation between aneuploidy and growth in the Pacific oyster, Crassostrea gigas: ten years of evidence. Aquaculture, in press.

McFadden, D.E., and Friedman., J.M. 1997. Chromosome abnormalities in human beings. Mutat. Res. 396: 129-140.

Martin, R.H. and Rademaker, A. 1990. The frequency of aneuploidy among individual chromosomes in 6,821 human sperm chromosome complements. Cytogenet. Cell Genet. 53: 103-107.

Oshiro, G., and Winzeler, E. 2000. Aneuploidy-it's more common than you think. Nature Biotechno. 18: 715-716.

Rupa, D.S., Schuler, M., and Eastmond, D.A. 1997. Detection of hyperdiploidy and breakage affecting the 1cen-1q12 region of cultured interphase human lymphocytes treated with various genotoxic agents. Environ. Mol. Mutagen. 29: 161-167.

Sumner, A.T., Evans, H.J., and Buckland, R.A. 1971. New technique for distinguishing between human chromosomes. Nature 232: 31-32.

Thiriot-Quiévreux, C. 1986. Étude de l'aneuploïdie dans differents naissains d'Ostreidae (Bivalvia). Genetica 70: 225-231.

Thiriot-Quiévreux, C., and Ayraud, N. 1982. Les caryotypes de quelques espèces de Bivalves et de Gastéropodes marins. Mar. Biol. 70: 165-172.

Thiriot-Quiévreux, C., and Insua, A. 1992. Nucleolar organiser region variation in the chromosomes of three oyster species. J. Exp. Mar. Biol. Ecol. 157: 33-40.

Thiriot-Quiévreux, C., Pogson, G.H., and Zouros, E. 1992. Genetics of growth rate variation in bivalves: aneuploidy and heterozygosity effects in a Crassostrea family. Genome 35: 39-45.

Verma, R.S. 1983. Preferential association of nucleolar organising human chromosomes as revealed by silver staining technique at mitosis. Mol. Gen. Genet. 190: 352-354.

Verma, R.S. 1988. Heterochromatine: Molecular and Structural aspects. Cambridge University Press, New York.

Verma, R.S. 1990. The Genome. VCH Publishers incorporated. 
Vig, B.K., and Miltenburger, H.G. 1976. Sequence of centromere separation of mitotic chromosomes in Chinese hamster. Chromosoma 55: 75-80.

Vig, B.K., and Sandberg, A.A. 1987. Aneuploidy: part A. Incidence and Etiology. Alan R. Liss, New York.

Wang, Z., Guo, X., Allen, S.K., and Wang, R. 1999. Aneuploid Pacific oyster (Crassostrea gigas Thunberg) as incidentals from triploid production. Aquaculture 173: 347-357.

Wenger, S.L., Golden, W.L., Dennis S.P., and Steele, M.W. 1984. Are the occasional aneuploid cells in peripheral blood cultures significant? Am. J. Med. Genet. 19: 715719. 